\title{
PENDIDIKAN KARAKTER DALAM MATA PELAJARAN ANTROPOLOGI MELALUI METODE FIELD TRIP: STUDI KASUS HUMA BETANG TUMBANG GAGU SEBAGAI KATALISATOR NASIONALISME SISWA
}

\author{
Renny Veronika Marbun \\ MAN Sampit, Kalimantan Tengah \\ reniveronika@gmail.com
}

\begin{abstract}
Abstrak
Penelitian ini bertujuan untuk mengetahui pendidikan karakter melalui metode field trip mata pelajaran Antropologi pada studi kasus Huma Betang Tumbang Gagu. Metode pengambilan data dilakukan melalui wawancara dan observasi dengan teknik pengambilan sampel penelitian yaitu purposive sampling. Kegiatan field trip ke Huma Betang Tumbang Gagu dapat menjadi katalisator nasionalisme siswa seperti sikap toleransi, gotong royong maupun musyawarah dalam pengambilan keputusan bersama. Implementasi falsafah-falsafah yang didapatkan dalam penelitian ini dapat menjadi fondasi siswa dalam berkembang menjadi warga negara Indonesia yang menjaga keutuhan bangsa dalam bingkai Pancasila.
\end{abstract}

\section{Kata kunci: Antropologi, Field Trip, Huma Betang, Nasionalisme, Tumbang Gagu}

\section{Pendahuluan}

Indonesia sebagai negara berkembang memerlukan sumber daya manusia yang mampu bersaing dan berjuang dalam membangun bangsa. Sumber daya manusia yang dimaksud merupakan individu dengan karakter nasionalisme yang kuat. Pendidikan formal di sekolah merupakan salah satu upaya dalam meningkatkan karakter bangsa. Karakter bangsa yang diimplementasikan melalui berbagai metode pembelajaran kepada siswa diharapkan mampu menghasilkan individu yang menjadi solusi dalam pembangunan negara.

Antropologi sebagai salah satu cabang ilmu yang diajarkan pada pendidikan formal memiliki fungsi yang sama dalam pembentukan karakter bangsa. Pemahaman mengenai manusia sebagai makhluk sosial dengan memperhatikan sifat maupun budayanya diperlukan dalam membentuk karakter baik pada siswa. Penanaman karakter yang baik tidak hanya dalam pengenalan nilai dan norma sosial saja, akan tetapi harus direalisasikan dalam kehidupan.

Dalam pendidikan formal khususnya bidang studi Antropologi dapat digunakan berbagai metode pembelajaran untuk mencapai tujuan besar pendidikan yaitu penanaman karakter bangsa, salah satu metode tersebut yaitu field trip. Studi lapangan yang langsung melihat kondisi permasalahan maupun apresiasi suatu budaya merupakan langkah jitu dalam pengembangan karakter siswa. Nilai kebudayaan dapat diambil sebagai salah satu bahan pembelajaran karakter bangsa.

Bangsa Indonesia mempunyai masyarakat yang majemuk dengan berbagai macam kebudayaan, kemajemukan inilah yang dapat meningkatkan jiwa nasionalisme siswa dimana pemahaman akan perbedaan bukanlah sebuah kelemahan melainkan kekuatan bangsa perlu ditanamkan. Perbedaan tersebut merupakan realitas sosial yang memang sudah seharusnya terjadi dalam kondisi masyarakat heterogen. Jika dikaitkan kembali dengan permasalahan bangsa yang saat ini sering terjadi seperti masalah SARA dan kurangnya nasionalisme bangsa, maka keberadaan ikrar satu nusa dan satu bangsa serta satu bahasa sangat perlu untuk digiatkan kembali dalam konstruksi masyarakat Indonesia sekarang terutama pada siswa yang merupakan sumber daya manusia dalam membangun negara. Pembangunan karakter menjadi kunci utama dalam mencapai tujuan tersebut.

Karakter berasal dari bahasa Latin dengan 
arti dipahat, dimana menunjukkan kualitas dan kekuatan moral maupun mental. Karakter sendiri merupakan sebuah ciri khas dari individu dimana mempunyai kaitan sangat erat dengan kepribadian seseorang yang menjadi pengendali atas tindakan, sikap, serta respons akan sesuatu (Asmani, 2011). Karakter mempunyai asosiasi dengan temperamen sehingga melahirkan adanya kaitan unsur psikososial dengan lingkungan dan pendidikan. Apabila dilihat dari sudut perilaku maka karakter didefinisikan pada unsur somatopsikis yang dimiliki setiap orang dari lahir. Karakter bersumber dari bentukan yang diterima dari kecil hingga penetapan jati diri, bahkan akan terus berkembang jika masih ada stimulus untuk pembentukan karakter tersebut (Majid dan Andayani, 2011).

Karakter mulia harus dimiliki oleh peserta didik melalui pendidikan formal maupun nonformal. Pendidikan formal yang berkaitan dengan implementasi pembelajaran di sekolah dan non-formal dapat diserap dari lingkungan seperti keluarga dan sebagainya. Pendidikan sebagai usaha yang terencana agar peserta didik dapat secara aktif mengembangkan kepribadian luhur, kecerdasan, kekuatan spiritual keagamaan yang kuat serta pengendalian diri maupun nasionalisme tinggi. Pendidikan karakter ini mendidik siswa dalam pengambilan keputusan yang bijak dan mampu diimplementasikan dalam kehidupan seharihari, sehingga pada luarannya yaitu tindakan positif dalam bermasyarakat (Kesuma, 2011).

Pengetahuan akan potensi diri seperti rasional, kritis, analitis, logis, mandiri, bertanggung jawab dan sebagainya merupakan contoh dari karakter mulia yang diharapkan akan dicapai siswa dalam pembelajaran yang terintegrasi. Perkembangan positif individu direalisasikan dalam bentuk karakter yang sadar secara penuh untuk melakukan tindakan terpuji dan mengetahui batasan tindakannya baik secara emosional, perilaku, etika dan sosial serta intelektual. Siswa yang berkarakter baik dan unggul akan melakukan hal positif yang berguna baik untuk dirinya maupun lingkungannya. Pendidikan karakter tersebut jika ditelaah kembali terbagi menjadi tiga ide pokok yaitu transformasi nilai-nilai, penanaman dalam kepribadian dan menjadi satu dalam kompleks kehidupan siswa tersebut (Kesuma, 2011).

Internalisasi nilai-nilai dengan sifat formal terjadi dalam pendidikan formal, dan masih terbatas dalam lingkup keluarga. Pendidikan berpengaruh dalam proses perkembangan jiwa maupun perilaku siswa. Kurangnya pendidikan menjadikan individu lebih mengutamakan kebutuhan biologis dalam pengambilan keputusan sehingga tidak bersifat objektif serta lebih banyak melanggar norma-norma sosial.

Proses pembelajaran yang baik dapat dilaksanakan dengan berbagai macam metode, salah satunya adalah field trip. Metode field trip merupakan salah satu cara mengajar dengan melakukan kunjungan beserta peserta didik ke suatu tempat atau objek tertentu dalam rangka melengkapi pembelajaran. Keuntungan yang didapatkan dari metode ini yaitu merupakan teknik pengajaran dengan memanfaatkan lingkungan dalam proses pembelajaran. Selain itu mampu merangsang kreativitas peserta didik. Kesempatan pengamalan teori dapat langsung diterapkan di lapangan baik teori nilai maupun norma sosial (Djamarah, 2008).

Metode ini dapat menjadi salah satu cara terbaik dalam mengeksplorasi kemampuan siswa. Persiapan yang matang merupakan kunci kesuksesan dalam penerapannya. Lima langkah penting yang perlu diperhatikan yaitu menentukan tujuan serta sasaran utama, kemudian melihat semua pilihan serta pembuatan rencana perjalanan. Selanjutnya memeriksa daftar tujuan yang akan dicapai. Langkah terakhir yaitu melanjutkan hasil field trip dengan analisa di dalam kelas baik dalam tugas terstruktur maupun tidak (Djamarah, 2008).

Antropologi sebagai salah satu ilmu yang mempelajari budaya dan sosial masyarakat sangat memerlukan metode ini dalam proses ekstraksi ilmu kepada siswa. Kehidupan masyarakat yang multikultural menjadikan field trip sebagai salah satu pilihan metode pengajaran terbaik untuk meningkatkan kualitas karakter siswa. Kebudayaan Indonesia yang kaya akan makna dapat diteliti dengan metode ini, sehingga siswa secara langsung 
memahami nilai-nilai leluhur yang bertujuan dalam peningkatan nasionalismenya. Salah satu kebudayaan di Indonesia yaitu Huma Betang yang terdapat pada masyarakat Dayak Kalimantan Tengah.

Huma Betang dapat dilihat sebagai sebuah konsep pembangunan makro dengan integrasi berbagai macam unsur yang dapat mendukung pelaksanaan pembangunan. Perlambangan konsep tersebut berupa rumah besar dengan fungsi sebagai tempat tinggal masyarakat dengan corak pluralitas agama serta budaya. Masyarakat tersebut tinggal di dalam sebuah rumah besar yang terdiri dari sejumlah kamar sebagai wujud dari kebersamaan dengan dipimpin oleh seorang kepala suku yang disebut Bakas Lewu (Abubakar, 2016).

Tujuan dari penelitian ini yaitu mengetahui peran Antropologi dalam memfasilitasi pendidikan karakter siswa, serta falsafah dan nilai-nilai persatuan yang terdapat di Huma Betang Tumbang Gagu serta menjadikannya sebagai salah satu solusi masalah nasional dalam hal kebhinekaan serta sebagai katalisator nasionalisme siswa.

\section{Metode Penelitian}

Field trip dilaksanakan dari bulan April hingga minggu pertama bulan Juni tahun 2017. Kunjungan ini bertempat di Huma Betang Tumbang Gagu yang terletak di Kecamatan Antang Kalang, Kabupaten Kotawaringin Timur. Field trip ini tidak hanya sekedar mengunjungi lokasi rumah adat akan tetapi juga dilakukan discovery learning agar siswa lebih dapat mengambil esensi kunjungan.

Cara kerja dalam penelitian pada field tip ini dimulai dari permohonan izin kepada Dinas Pariwisata pada bulan April hingga Mei, hal ini karena Huma Betang Tumbang Gagu termasuk area promosi pariwisata. Selain kepada Dinas Pariwisata, permohonan ijin dan pengajuan biaya juga disampaikan kepada pihak madrasah. Tak terkecuali meminta izin orang tua mengingat secara geografis untuk sampai ke objek penelitian jaraknya cukup jauh dan harus melalui aliran sungai yang deras ditambah terdapat banyak riam atau batu-batu besar. Hal ini dilakukan secara tidak langsung guna memberikan suatu proses pembelajaran tentang perlunya proses administrasi untuk diketahui siswa.

Langkah berikutnya guru mempunyai peran strategis dalam memperkenalkan bagaimana metode field trip kepada siswa. Membentuk beberapa tim work untuk melakukan discovery learning dengan harapan siswa dapat menemukan local wisdom yang terdapat pada suku bangsa Dayak di Kalimantan Tengah. Proses datamining menggunakan metode wawancara serta observasi dan juga diikuti dengan penyusunan kuesioner. Kuesioner yang dibagikan dirancang berdasarkan pengetahuan yang dimiliki baik berasal dari buku maupun jurnal yang telah dibahas di kelas sebelumnya. Perumusan pertanyaan yang spesifik bertujuan agar mendapatkan informasi yang lebih mendalam dan spot on. Selain wawancara dan kuesioner ada juga dilakukan observasi secara detail sebagai salah satu cara untuk mengamati tindakan dan perilaku para penghuni Huma Betang Tumbang Gagu. Siswa juga mengukur luas area bangunan Huma Betang, tidak lupa mencari data tentang alat dan bahan yang digunakan dan cara membangun Huma Betang. Subjek penelitian yaitu beberapa tokoh adat yang tergabung dalam Lembaga Masyarakat Dayak Kalimantan Tengah (LMDKT), selain itu ada juga aparatur desa seperti pembakal (kepala desa), mantir (penasihat adat) dan pangulu (tokoh yang mengurusi tentang agama), dan menggali informasi dari para penghuni Huma Betang itu sendiri.

Wawancara dilakukan secara tidak terstruktur kepada pihak-pihak yang dipandang representatif terkait dengan persoalan penelitian. Total responden yang diinterview secara langsung sebanyak enam orang, dimana merupakan keluarga yang masih tinggal di Huma Betang. Cara ini dilakukan untuk memperoleh informasi dari responden secara valid dan terperinci. Data yang diperoleh dalam bentuk deskriptif akan dianalisis dengan metode kualitatif, yaitu mendeskripsikan secara detail tentang Huma Betang sebagai bentuk harmonisasi perekat kebhinekaan, dan menganalisis nilai-nilai persatuan antar sesama yang terkandung dalam Huma Betang 
sebagai solusi permasalahan nasional dalam hal kebhinekaan di Indonesia.

Teknik pengambilan sampel penelitian menggunakan teknik purposive sampling (sampel bertujuan). Teknik ini dipilih karena merupakan teknik yang sangat tepat untuk mendapatkan data tentang Huma Betang baik itu berdasarkan ciri dan karakteristik yang terdapat pada Huma Betang, serta menggali informasi tentang Huma Betang sebagai bentuk harmonisasi perekat kebhinekaan. Selain itu purposive sampling dipilih agar data yang diinginkan berasal dari subjek representatif yang tepat.

Pengumpulan data penelitian yang bertujuan untuk mengumpulkan data dengan menggunakan metode observasi maupun interview tentang hunian masyarakat Dayak Kalimantan Tengah Huma Betang Tumbang Gagu. Perjalanan untuk mengumpulkan data ke Huma Betang Tumbang Gagu dilaksanakan tanggal 6-8 Juni 2017. Diawali perjalanan darat dari Kota Sampit ke Kecamatan Antang Kalang selama kurang lebih 5 jam, dengan jarak $190 \mathrm{~km}$. Tim peneliti menginap satu malam di Kecamatan Antang Kalang dan esok paginya tanggal 7 Juni 2017 pukul 05.00 WIB baru bisa melakukan perjalanan, hal ini untuk mengantisipasi surutnya debit air di sungai. Perjalanan melalui transportasi air menggunakan perahu (klotok) dengan bermesin diesel L disupiri Bapak Dulas yang memang sangat mahir dengan situasi dengan kondisi air di sungai menuju Huma Betang Tumbang Gagu. Perjalanan ditempuh selama 4,5 jam, melewati enam desa yaitu desa Tekuluk Telawang, Sungai Puring atau Pahilet, Tumbang Ngahan, Tumbang Rame, Tumbang Hejan, dan desa Buntut Nusa.

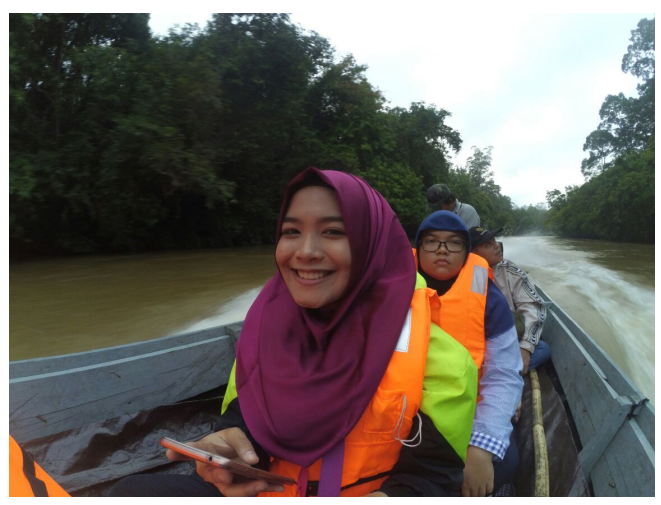

Gambar 1. Perjalanan Siswa dan Guru menuju Huma Betang (Dokumentasi Pribadi)

Dalam perjalanan siswa dan guru pembimbing (Gambar 1) dihadapkan dengan kuatnya arus sungai dan ditambah banyaknya riamriam (batu-batu besar) di sekitar sungai yang cukup mengganggu perjalanan. Kondisi pohon tumbang di sekitar sungai juga menambah faktor penghambat dalam perjalanan tim peneliti menuju tempat penelitian. Ketika sampai ke subjek penelitian Huma Betang Tumbang Gagu, tim peneliti harus melewati empat tangga dengan jumlah anak tangga yang berbeda-beda. Tangga pertama memiliki anak tangga sebanyak enam buah, lalu papan yang tersusun secara horizontal sebagai lantai, dilanjutkan dengan tangga kedua dengan jumlah anak tangga tujuh buah, dan untuk melewati tangga ketiga dengan anak tangga 17 buah, kemudian terdapat papan lantai sebagai tempat alas kaki para penghuni atau tamu yang akan masuk. Tangga terakhir untuk masuk ke Huma Betang Tumbang Gagu memiliki anak tangga lima buah. Setelah memasuki Huma Betang maka sesi observasi maupun interview dilaksanakan. Dokumentasi baik secara audio visual menggunakan handycam maupun pencatatan dalam blocknote dilakukan. 


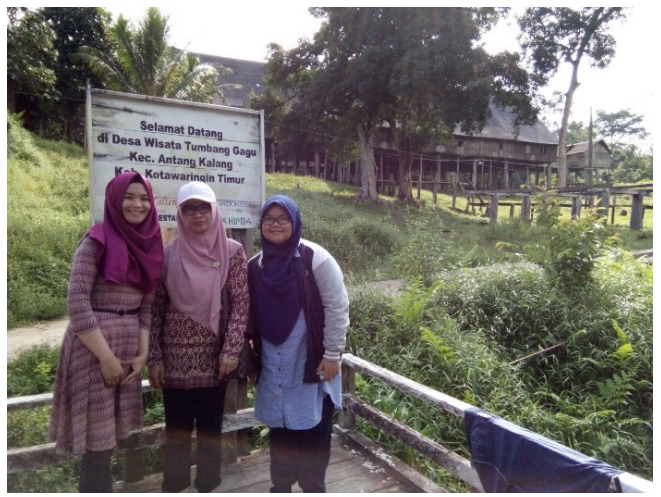

(A)

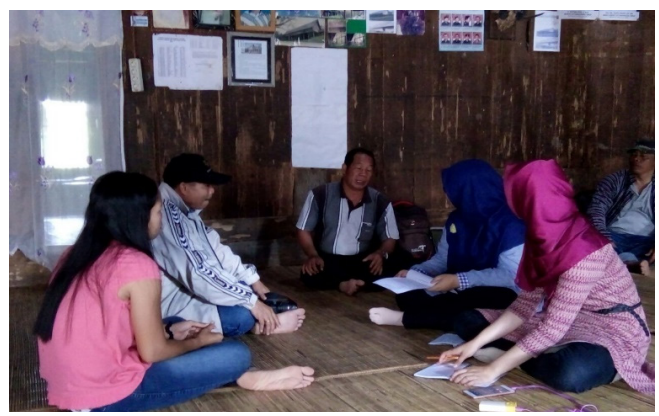

(B)

Gambar 2. Field Trip di Huma Betang

Tumbang Gagu (A) Siswa beserta guru pembimbing tiba di Huma Betang Tumbang

Gagu (B) Siswa melakukan wawancara dengan narasumber (Dokumentasi Pribadi)

Setelah beberapa troubleshooting diselesaikan pada akhirnya dua siswa berhasil mengikuti tahapan field trip dari tahap awal hingga tahap akhir dengan baik. Siswa yang telah berhasil diminta untuk mengekstraksi nilai-nilai sosial yang telah mereka peroleh kepada temantemannya. Hal ini bertujuan agar nilai-nilai sosial yang telah siswa temukan di Huma Betang Tumbang Gagu melalui field trip akan terimplementasikan dalam kehidupan seharihari.

\section{Hasil dan Pembahasan}

\section{Analisis Makna dari Struktur Huma Betang}

Huma Betang Tumbang Gagu (Gambar 3) secara administratif berada di Desa Tumbang Gagu, Kecamatan Antang Kalang, Kabupaten Kotawaringin Timur, Provinsi Kalimantan Tengah. Huma Betang Tumbang Gagu memerlukan tujuh tahun dalam segi pembangunannya dimulai dari tahun 1870 serta ditempati pada tahun 1878 . Pada awalnya Huma Betang Tumbang Gagu diisi oleh enam kepala keluarga yaitu Boruk Dawut, Pangkong Iding Dandu, Singa Jaya Antang Kalang, Manis Bin Lambang Dandu, Rais Bin Lambang Dandu serta Bunter dan Karamu. Salah satu pendiri dari Huma Betang Tumbang Gagu yaitu Singa Jaya Antang merupakan tokoh dalam perjanjian Tumbang Anoi. Perjanjian tersebut melibatkan semua suku Dayak di Kalimantan, dimana hasilnya berupa penyelesaian konflik di antara suku-suku tersebut, selanjutnya hasil berupa penghentian tradisi ngayau (Rahman, 2014).

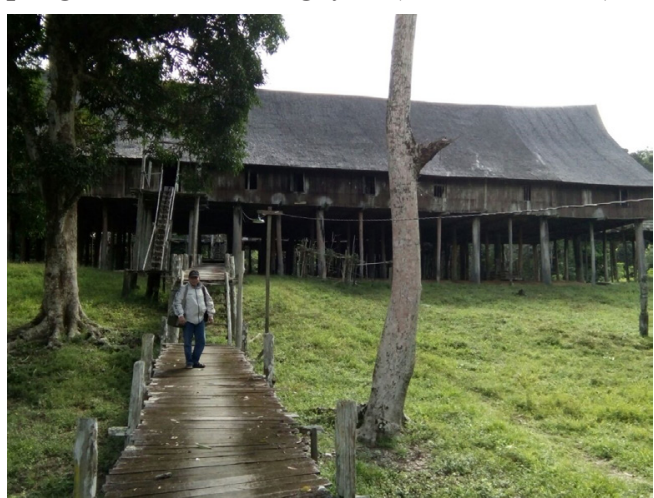

Gambar 3. Huma Betang Tumbang Gagu

(Dokumentasi Pribadi)

Luas lahan dari Huma Betang Tumbang Gagu sebesar $1.880 \mathrm{~m} 2$ dengan rupa rumah panjang berbentuk persegi empat panjang dengan ukuran panjang bangunan $58,7 \mathrm{~m}$, tinggi 15 , $68 \mathrm{~m}$ serta lebar 26,40 m. Dilengkapi dengan tiang-tiang dimana terdiri dari tiang jihi dan tungket sebanyak 256 tiang dengan ukuran yang bervariasi. Hejan (tangga) terdapat pada bagian depan maupun belakang rumah yang terbuat dari kayu ulin dengan tinggi 7,10 m dengan diameter $35 \mathrm{~cm}$ serta memiliki 20 anak tangga (Rahman, 2014).

Dari hasil observasi lapangan diketahui bahwa pembagian ruang dalam rumah betang terdiri dari balai kandang yang terletak di tengahtengah bangunan. Terdapat pula dua buah meriam yang dibeli oleh Antang Kalang. Selain itu terdapat bilik dalam Huma Betang sebanyak enam buah yang ditempatkan di samping kiri dan kanan balai. Jumlah balai tersebut didasari dari keenam pendiri Huma Betang dengan 
urutan dari hulu ke hilir yaitu Boruk Dawut, Pangkong Iding Dandu, Singa Jaya Antang Kalang, Manis bin Lambang Dandu, Rais bin Lambang Dadu, Bunter dan Karamu.

Pada bagian depan bilik yang menghubungkan masing-masing ruang terdapat aula serta teras pada bagian belakang dan samping sebagai penghubung antara bangunan utama dan dapur (Gambar 4) yang dibuat terpisah dengan bangunan utama. Pada sisi belakang dan samping Huma Betang terdapat enam dapur yang sesuai dengan jumlah kepala keluarga pada waktu itu. Saat ini yang masih utuh hanya bersisa dua dapur sedangkan sisanya sudah mengalami kerusakan parah dan ada yang roboh. Terdapat asosiasi Huma dengan lumbung yang berada di dekat selasar akan tetapi kini hanya tinggal tiang saja. Keberadaan sapundu, sandung serta tiang pantar yang diletakkan pada halaman depan.

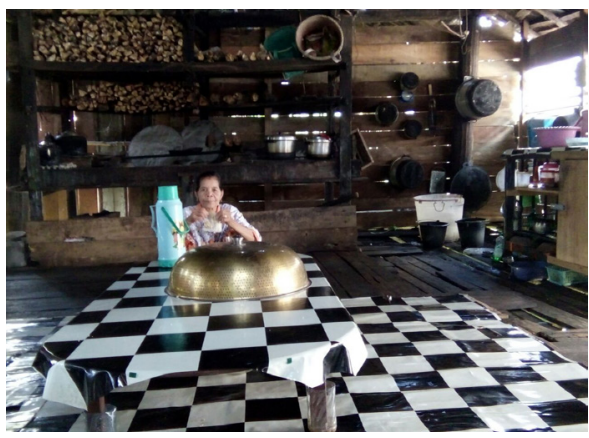

Gambar 4. Kondisi salah satu dapur Huma Betang Tumbang Gagu

(Dokumentasi Pribadi)

Jumlah sapundu yaitu 12 buah dengan penempatan di dekat sandung disebut sebagai sapundu gapit. Sedangkan sapundu juga terdapat di pinggiran Sungai Kalang disebut sebagai sapundu lepas. Jumlah sandung sebanyak satu buah dan terletak di tengah tengah halaman depan betang. Tiang pantar berjumlah sembilan tiang dan letaknya berdekatan dengan sandung. Kondisi dari sapundu, sandung serta tiang pantar sebagian mengalami kerusakan berupa patah, pelapukan maupun keretakan.

Hasil dari kuesioner yang diberikan kepada masyarakat suku Dayak Ngaju (berjumlah tiga orang) dalam pemahaman mengenai Huma
Betang, pertanyaan yang diberikan lebih ke arah Huma Betang baik tentang proses pembuatan, fungsi serta ciri-cirinya. Dari data kuesioner dapat disimpulkan secara garis besar Huma Betang merupakan tempat tinggal dari suku Dayak dengan ciri-ciri berbentuk panjang dan memiliki bilik-bilik dengan tujuan berbeda baik sebagai tempat tidur, tempat musyawarah, maupun dapur, serta tempat penyimpanan alatalat. Untuk penentuan individu yang boleh tinggal biasanya dilakukan oleh pemimpin di rumah adat tersebut. Penentuan bilik juga dipimpin oleh bakas lewu dan dilaksanakan secara musyawarah.

Selain kuesioner dilakukan pula interview dengan warga asli penghuni dari Huma Betang Tumbang Gagu. Responden terdiri dari Bapak Labuan U. Antang berusia 85 Tahun, Ibu Lerie Levin berusia 32 Tahun, Ibu Sille berusia 63 Tahun, Bapak Dulas berusia 35 Tahun. Wawancara juga dilakukan dengan Bapak Pungkal berusia 55 Tahun, serta Bapak Lipsin berusia 52 Tahun. Dari wawancara langsung yang dilakukan oleh tim peneliti didapatkan data yaitu rumah tersebut telah berumur 147 tahun dengan jumlah bilik yang disesuaikan dengan pendiri rumah adat tersebut dahulu yaitu sejumlah enam bilik. Pembangunan rumah adat diutamakan di sekitar pesisir untuk lebih memudahkan mobilitas masyarakat melalui transportasi air. Huma Betang juga dibangun dalam rangka memberikan perlindungan kepada individu-individu penghuni baik dari alam, hewan buas maupun suku lainnya. Bagian dalam bangunan terdiri dari bilik, dapur, sandung, tangga, sapundu, tiang pantar dan ruang pertemuan.

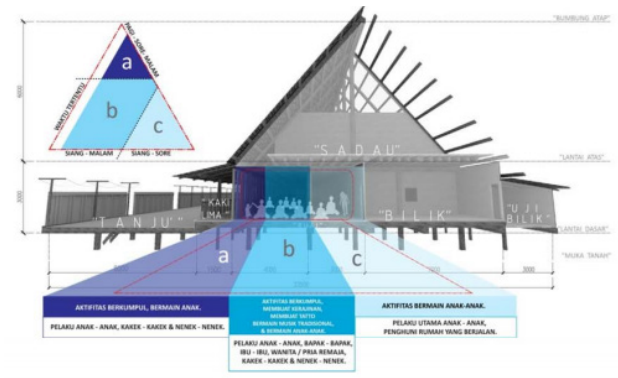

Gambar 5. Pelaku aktivitas harian di Huma Betang (Hafiid dkk, 2015) 
Menurut Haffid dkk (2015), menyatakan bahwa pembentukan bilik terjadi karena beberapa aktivitas harian yaitu aktivitas bermain anak-anak, berkumpul membuat kerajinan, tatto, bermain musik tradisional dan bahkan bermusyawarah. Batas ruang ditentukan oleh aktivitas baik dalam waktu bersamaan atau pergantian waktu. Beberapa ruang seperti tempat tidur dan dapur mempunyai intensitas penggunaan yang lebih sering. Peningkatan interaksi menandakan adanya interaksi baik antara satu keluarga, satu kelompok keluarga maupun antar individu serta antara tamu dan penghuni maupun antar warga penghuni rumah. Ruang bersama cenderung mempunyai intensitas penggunaan yang tinggi. Pembentukan bilik menunjukkan dinamika ruang dan pembentukan ruang bersifat fleksibel dan temporal.

\section{Nilai Sosial dari Konstruksi Masyarakat Penghuni Huma Betang}

Huma Betang dalam pandangan masyarakat Dayak selain digunakan sebagai tempat hunian, juga difungsikan sebagai tempat berkumpul keluarga, pertemuan adat, musyawarah, tempat berlindung dari serangan binatang buas dan wujud dari semangat kebersamaan. Huma Betang secara filsafat menyatukan sesama penghuni yang tinggal di dalamnya. Hal ini sesuai dengan pola pikir masyarakat Dayak yang memiliki keinginan untuk tinggal bersama-sama dalam satu tempat. Berdasarkan hasil interview dengan penghuni Huma Betang Tumbang Gagu didapatkan beberapa falsafah baik dari arti hunian bagi warganya maupun falsafah hidup yaitu: "Huma Betang itu rumah dengan kebersamaan dan suka cita di dalamnya (Bapak Labuan U. Antang), Huma Betang adalah rumah kami, tempat kami bergotong royong dan hidup harmoni (Bapak Dulas dan Bapak Lipsin)". Falsafah kehidupan di Huma Betang Tumbang Gagu yaitu: "Harobuk nak yaitu kerja sama dengan kada beharap timbal balik, hidup damai lawan penuh toleransi (Bapak Labuan U. Antang). Huma Betang adalah tempat penuh kejujuran dan kebersamaan antar individu keluarga (Ibu Lerie Levin). Setau saya hidup penuh toleransi dan beban hidup dipikul bersama adalah inti dari hidup di Huma Betang (Bapak Dulas). Tetap ae hidup dengan belom bahadat dan junjung tinggi semangat isen mulang (Bapak Lipsin). Hidup di sini tu penuh dengan adat istiadat, anak harus hormat sama yang tua contohnya kaki diangkat amun lewat orang tua tidur, kan kayunya bunyi nanti ganggu tidur orang tua nak ae kaya itu jua sama manggil orang tua kada boleh sembarangan manggil nama. Ada jua bahasa Habatang Garing Habaner Garantung Habasung Runjan itu tu artinya lelakian wajib hukumnya menghormati dan menjaga kehormatan perempuan nak ae (Ibu Sille)."

Persatuan dalam kehidupan sehari-hari tidak jauh dari teori multikulturalisme yang secara sadar maupun tidak adalah keadaan sosial dalam bermasyarakat. Masyarakat Dayak dalam kehidupan sehari-harinya di Huma Betang telah menerapkan nilai tersebut agar menghindari disintegrasi sosial. Kemampuan menahan ego dan amarah demi kebaikan bersama mendukung terciptanya suasana kebhinekaan. Tidak terdapat golongan atas, menengah maupun bawah dalam kehidupan warga di Huma Betang Tumbang Gagu. Keberadaan pemimpin tidak menjadikan sistem kehidupan berdasarkan otoriter. Pemusyawarahan merupakan ujung dari pemecahan setiap gesekan di antara penghuni Huma Betang.

"Musyawarah tetap lestari buktinya setiap pengambilan keputusan akan dilaksanakan di Balai Garadu. Kalau ada perselisihan antara warga maka ketua adat akan memimpin pertemuan untuk mengambil keputusan bersama (Bapak Labuan U. Antang)". Indonesia sebagai bangsa yang majemuk dengan kondisi masyarakat yang plural terkadang masih bisa mengalami perpecahan baik karena isu politik maupun agama serta sosial, terutama akhir-akhir ini. Kepentingan golongan tertentu berusaha menekan anggota lainnya sehingga menciptakan konflik. Konflik yang berkepanjangan mampu mengancam keutuhan Indonesia sebagai suatu bangsa. Kondisi plural juga terjadi di masyarakat Dayak yang tinggal di Huma Betang Tumbang Gagu, namun keberadaan agama yang berbeda 
bukanlah menjadi penghalang dalam kerukunan antar penghuni. Seperti yang dapat dilihat bahwa hampir semua warga Huma Betang menyatakan bahwa kerjasama dan toleransi menjadi tiang falsafah yang kokoh dalam kehidupan mereka sehari-hari. Pernyataan responden menunjukkan bahwa keberadaan nilai-nilai persatuan sangat kental di Huma Betang Tumbang Gagu. "Nilai persatuan yang ada yaitu toleransi baik adat terhadap orang tua, maupun toleransi agama. Di Huma Betang ini ada penghuni yang beragama Islam, Kristen, dan Hindu Kaharingan. Kalau ada kegiatan agama misalnya tiwah, kebaktian maupun kegiatan keagamaan lainnya pasti saling membantu supaya kegiatan terlaksana dengan lancar (Bapak Dullas).'”

Hal yang sama juga diungkapkan Ibu Sille "agamanya ada Islam, Hindu Kaharingan dan Kristen dan sukunya adalah Dayak Ngaju, mata pencaharian bahuma, berburu, dan menangkap ikan. Bukan hanya dari segi keagamaan saja yang menunjukkan sikap persatuan akan tetapi dari pekerjaan sehari-hari juga mencerminkan sikap tersebut. Gotong royong juga terpatri dalam tindakan masyarakat penghuni Huma Betang Tumbang Gagu sehari-hari. Tanpa disadari sifat tersebut menjadi jiwa dari kegiatan sehari-hari sehingga frekuensi konflik yang terjadi dalam kategori sangat rendah.

"Seperti biasa ada kegiatan bahuma, maunjun, menggalau iwak, membuat tikar dari uwei. Uwei tu rotan nak ae, lalu ada jua membuat sipet atau sumpit (Bapak Dulas). Gotong royong? Ya itu pang kaya tadi ada harobuk di bidang bahuma, menggalau iwak, buat rotan, lawan tiwah (Ibu Sille)". Situasi yang majemuk tidak menyurutkan semangat kebersamaan yang juga tanpa disadari merupakan pilar dari kebhinekaan. Situasi ekonomi di Huma Betang juga memiliki keunikan sendiri yaitu adanya kondisi mandiri dan gotong royong. Hal ini terlihat dari hasil jawaban kuesioner yang diberikan kepada beberapa responden masyarakat Dayak. Harobuk atau gotong royong yang disampaikan oleh responden memang diwariskan secara turun temurun. Gotong royong dalam masyarakat Dayak dapat dilihat dari proses pembangunan
Huma Betang. Proses pembangunan dimulai dari mendirikan bangunan dengan upacara mampendeng, dimana dari jihi bakas hingga jihi bisu. Menurut kepercayaan suku Dayak bahwa dalam membangun Huma Betang sangat dipengaruhi dengan tata cara maupun waktu mulai pembangunan (Rahman, 2014). Falsafah dari adat tersebut yaitu dengan mengikuti semua aturan dan proses tanpa disadari bahwa masyarakat secara langsung menerapkan sifat taat dan patuh dengan peraturan yang dibuat bersama, sehingga luaran yang dihasilkan adalah kerukunan antar penghuninya. Peletakan Huma Betang di pinggiran sungai mengingat bahwa kondisi geografis pulau Kalimantan didominasi dengan sungai-sungai. Sehingga untuk akses transportasi maupun sarana komunikasi dan ekonomi, masyarakat harus beradaptasi dengan lingkungan (Rahmat, 2014). Kemampuan penyesuaian diri inilah yang membuat masyarakat Dayak ramah dengan pendatang dan mampu berbaur. Kesatupaduan dapat tercipta dengan sifat penerimaan yang besar dari individu penyusun masyarakat, akan tetapi tidak lupa untuk menjaga nilai kearifan lokal.

Falsafah lain yang tidak kalah penting yaitu minimalisasi gesekan sosial antar individu yang bertinggal di Huma Betang dengan musyawarah. Sebelumnya telah dijelaskan bahwa kepemimpinan terdapat dikonstruksi sosial masyarakat Dayak. Pemimpin dihormati karena merupakan sosok representatif dari masyarakat. Pengambilan keputusan dalam menghadapi suatu masalah dapat dilihat dari pola perilaku yang diambil ketika terjadi konflik tersebut. Pola tersebut tidak lepas dari musyawarah untuk mencapai mufakat. Menghargai pendapat serta mendengarkan sisi lain dari suatu permasalahan dengan dipimpin oleh pemimpin yang bijak, merupakan representasi dari kebhinekaan.

Selain tindakan represif aktif maupun kuratif yang dilaksanakan pada saat terjadi masalah, terdapat pula tindakan preventif yang dilakukan warga Huma Betang Tumbang Gagu. Tindakan preventif yang dilakukan contohnya adalah mengajarkan dari kecil kepada anak mengenai hidup dengan sopan santun dan 
beradab. Pembelajaran tersebut secara tidak langsung akan menjadi panduan hidup seorang anak menuju proses kedewasaan. Sifatsifat luhur yang ditanamkan dari kecil akan menjadi penghias kehidupan penuh rukun dan tentram. Keberadaan falsafah-falsafah di atas sudah seharusnya diterapkan dalam kehidupan bermasyarakat di zaman modern ini. Penyelesaian konflik baik agama, suku dan ras dapat dengan mudah tercapai jika masyarakat Indonesia mempunyai itikad dalam refleksi kearifan lokal.

\section{Implementasi Nilai Sosial Hasil Field Trip pada Kehidupan Siswa}

Falsafah-falsafah di atas kemudian diterapkan siswa dalam kehidupan seharihari. Nasionalisme dalam diri akan semakin tumbuh karena telah memahami keberadaan nilai-nilai mulia dari keberadaan masyarakat multikultur di Huma Betang Tumbang Gagu khususnya dan Indonesia secara umum. Evaluasi tentu saja terus dilakukan dimana siswa akan dilihat perkembangan kepribadian maupun intelektualitasnya dalam kelas. Dalam pembinaan karakter yang berkelanjutan guru sebagai tenaga pendidik terus memperhatikan berbagai faktor yang dapat mempengaruhi dinamika nilai-nilai dalam individu siswa. Pelaksanaan pembinaan menyeluruh justru baru dimulai setelah selesainya analisis serta ekstraksi nilai dari field trip di atas. Metode field trip dapat membantu siswa dalam pembelajaran yang lebih menyeluruh, dimana siswa langsung terjun ke lapangan (Dohn, 2013).

Nilai yang telah didapatkan oleh siswa baik melalui hasil wawancara maupun observasi serta pembahasan berupa diskusi menyeluruh kemudian guru mengambil peran yang sangat krusial yaitu melakukan implementasi nilai-nilai tersebut melalui forum diskusi serta renungan bersama. Pembinaan menyeluruh diharapkan dapat menyentuh jiwa dan nurani siswa yang paling dalam dimana dapat mencapai kesadaran integral dari siswa. Internalisasi nilai yang didapatkan dari field trip di atas baik berupa pentingnya nilai-nilai positif dari falsafah Huma Betang diharapkan menjadi pengalaman dan pengetahuan bagi siswa. Hal ini kemudian mampu menjadi katalisator nasionalisme siswa baik dalam berpikir maupun bertindak. Setelah melakukan tindakan tentunya akan timbul berbagai reaksi oleh siswa, meskipun reaksi yang ditimbulkan dapat berupa negatif, maka peran bimbingan guru masuk ke dalam sistem pola berpikir sehingga siswa dapat melakukan refleksi atas reaksinya. Renungan inilah yang diharapkan mampu membangun kesadaran jiwa akan kebaikan nilai-nilai kehidupan dalam pembentukan karakter mereka. Ketika karakter telah terbentuk maka sikap utuh akan tercapai dan luaran pendidikan untuk menghasilkan individu yang memberikan dampak positif bagi dirinya, lingkungan maupun bangsa dan negara dapat tercapai. Karakter yang kuat diharapkan mampu membawa siswa kepada kecerdasan intelektual, spiritual maupun emosional.

\section{Kesimpulan dan Saran}

Pendidikan karakter dalam proses pembelajaran meliputi pengenalan nilai dan norma sosial kemudian mengarahkan siswa dalam mencapai kesadaran akan nilai luhur bangsa sehingga pada akhirnya mampu mengimplementasikan ke dalam karakter individu. Karakter yang terbentuk akan secara langsung meningkatkan kualitas sumber daya manusia bangsa Indonesia. Penanaman nilai karakter melalui metode field trip dalam bidang ilmu Antropologi diharapkan mampu memperkuat nilai-nilai kearifan lokal pada siswa sehingga mampu menjadi katalisator nasionalisme siswa. Implementasi falsafah-falsafah yang terdapat pada Huma Betang Tumbang Gagu tersebut dapat dilaksanakan dalam kegiatan pendidikan, penyelenggaraan pemerintahan baik dalam aspek kedaulatan maupun kebebasan warga negara dalam mengemukakan pendapat. Tentu saja harus didasari dengan pemahaman pentingnya sebagai warga negara Indonesia yang satu bahasa, satu nusa dan satu bangsa. Dengan usaha dan perjuangan tersebut maka besar harapan dalam menjamin kelestarian, kelangsungan serta tetap kokohnya negarabangsa yang merdeka, bersatu, berkedaulatan rakyat dan berkeadilan rakyat dan berkeadilan sosial, yang dengan penuh semangat membangun manusia dan masyarakat yang 
maju, sejahtera, adil, dan makmur.

Pendidikan karakter hendaknya dilakukan oleh seluruh lembaga pendidikan. Penerapan pendidikan karakter dengan berbagai cara diharapkan mampu meningkatkan kecerdasan, moral, watak, serta kepribadian siswa yang mulia. Kemudian hendaknya guru tidak hanya memiliki peran sebagai pengajar saja akan tetapi juga merupakan seorang inspirator yang baik bagi peserta didiknya, sehingga keseluruhan sistem pendidikan berkarakter dan menghasilkan sumber daya manusia yang unggul untuk pembangunan bangsa Indonesia.

\section{Daftar Pustaka}

Abubakar, H.M. (2016). Huma Betang dan Aktualisasi Nilai Kearifan Lokal Dalam Budaya Dayak. Humanika. Vol.1, No. 2

Asmani, J.M. (2011). Buku Panduan Internalisasi Pendidikan Karakter di Sekolah. Yogyakarta : DIVA Press.

Dohn, N.B. (2013). Upper Secondary students situational interest : a case study of the role of a zoo visit in a biology class. International Journal of Science Education (16) : 2732-2751

Djamarah, S. B. (2008). Psikologi Belajar. Jakarta: Rineke Cipta.

Haffid, M.A., Antariksa, Ridjal, A.M. (2015). Ruang Bersama Pada Bangunan Rumah Panjae Suku Dayak Iban Kalimantan Barat. Arsitektur e-Journal, Volume 8 Nomor 1

Kesuma, D. (2011). Pendidikan Karakter Kajian Teori dan Praktik di Sekolah. Bandung: PT Remaja Rosdakarya.

Majid, A \& Andayani, D. (2011). Pendidikan Karakter Perspektif Islam. Bandung: PT Remaja Rosdakarya.

Rahman, F. (2014). Buku Panduan Wisata. Sampit: Dinas Kebudayaan dan Pariwisata 